\title{
Estimation and validation of mercury intake associated with fish consumption in an EPIC cohort of Spain
}

\author{
JM Sanzo ${ }^{1}$, M Dorronsoro ${ }^{1, *}$, P Amiano ${ }^{1}$, A Amurrio ${ }^{2}$, FX Aguinagalde ${ }^{2}$, MA Azpiri ${ }^{1}$ and \\ the EPIC Group of Spain \\ ${ }^{1}$ Health Department of the Basque Country, Public Health Division of Gipuzkoa, Avda. Navarra No. 4, 20013 San \\ Sebastian, Spain: ${ }^{2}$ Health Department of the Basque Country, Public Health Laboratory, C Santiago II, Vitoria, \\ Spain
}

Submitted 27 March 2000: Accepted 19 March 2001

\begin{abstract}
Objective: To estimate mercury intake due to fish consumption among the individuals from Gipuzkoa participating in the European Prospective Investigation into Cancer (EPIC), and to validate the estimation of mercury exposure through diet, by measuring blood mercury level.

Design and setting: The population for the EPIC Gipuzkoa cohort was recruited from 1992 to 1995. Each individual's diet was assessed regarding habitual intake over the previous year, using the diet history method. Blood samples were taken at the time of the interview. The mercury content of the fish species consumed was supplied by the Food Chemical Surveillance Programme in the Basque Country.

Subjects: For the estimation, 8417 volunteers, men and women, aged 35-65 years, of the EPIC cohort; for the validation, a random sample of 120 individuals stratified by fish intake was taken.

Results: The validation study confirmed the relationship between fish consumption and mercury intake, as well as between fish consumption and mercury in erythrocytes. $99.9 \%$ of individuals have intakes below $75 \%$ of the Provisional Tolerable Weekly Intake (PTWI) of mercury established by the World Health Organization. But the limit dosage recommended by the United States Environmental Protection Agency, measured by the average risk index, would be exceeded often. Conclusions: No individual from the cohort would exceed the PTWI of mercury. Nevertheless, owing to the amount of fish consumed, certain individuals would have mercury intakes approaching the recommended limits. With a view to the future, we believe mercury in fish must continue to be monitored closely in order to assess the risks for the population.
\end{abstract}

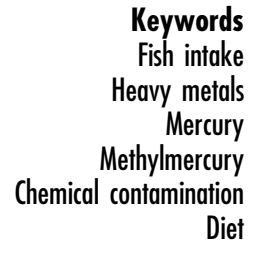

Mercury can be found in three forms: elemental mercury, inorganic mercury salts $\left(\mathrm{Hg}^{1+}\right.$ and $\mathrm{Hg}^{2+}$ ) and organic mercury ${ }^{1}$. Mercury is found in the Earth's crust mainly as sulphide compounds; cinnabar is the mineral richest in mercury, with a mercury content of up to $70 \%{ }^{2}$. Mercury in the atmosphere is a result of the evaporation of mercury from the ground and from water surfaces. The burning of fossil fuels, especially coal, also contributes to increasing the level of mercury in the atmosphere and also in natural cycles. Industrial wastes are the most significant source of mercury contamination in water. Air levels are increased as a result of solid wastes such as thermometers, batteries, electrical switches, mercurybased paints, pesticides and fungicides, and burning used oil ${ }^{1}$.

Any type of mercury compound may undergo a methylation process and turn into methylmercury through saprophyte micro-organisms found in soil and water ${ }^{1}$. Methylmercury is bioaccumulable in the aquatic food chain, reaching its highest concentrations in the edible tissues of larger fish, both freshwater and seawater. Methylmercury is not easily eliminated from these tissues and tends to accumulate during the life of the fish ${ }^{3}$.

Among organic mercury compounds methylmercury is the most toxic form. It is a neurotoxic agent present in the environment $^{4}$ and can easily pass through cellular membranes, therefore having a greater neurotoxic effect than mercury salts. In fish it has been stated ${ }^{1}$ that the proportion of methylmercury to inorganic mercury is high, of the order of 9:1.

Several studies carried out in various Western countries have indicated some variability in the mercury content of seawater and freshwater fish ${ }^{5,6}$. Similarly, some authors suggest that human exposure to mercury has been 
increasing in recent years ${ }^{7}$. Different epidemiological studies indicate the significance of fish intake as fundamental in estimating exposure to mercury ${ }^{8-10}$, due to the high rate of retention of methylmercury (90\% absorption rate). Dental fillings represent the most common source of inorganic mercury $8,11,12$. It has been suggested that the average daily uptake from amalgam is low, less than $1.4 \mu g^{13,14}$.

Some $90 \%$ of methylmercury is found in the red blood cells, where a small percentage is metabolised into mercury ions ${ }^{1}$. Total exposure is reflected in the blood, but the distribution of mercury between erythrocytes and plasma varies depending on its different chemical forms. Metallic and inorganic forms of mercury are distributed equally among erythrocytes and plasma, while exposure to methylmercury causes higher levels in erythrocytes than in plasma. As a result, mercury levels in erythrocytes (Ery-Hg) and mercury levels in plasma (P-Hg) may be used as indicators of methylmercury and inorganic mercury, respectively ${ }^{4,8,12,15}$. Absorbed methylmercury is excreted mainly in faeces (approximately 90\%) while inorganic mercury is excreted mainly in the urine ${ }^{1,16}$. It is estimated that the biological half-life of methylmercury in humans is 70 days, but there are wide variations among individuals (from 35 to 189 days) ${ }^{17}$.

A population that is not occupationally exposed to mercury nevertheless is exposed to organic and inorganic mercury from the environment, from food (mainly fish) and dental amalgams ${ }^{2,3,6}$. Among those not occupationally exposed to mercury, the most common source of mercury exposure is the diet; fish consumption is the greatest source of mercury, which logically depends on the level of contamination in each region ${ }^{1,11-18}$.

The Basque Country, as a result of its fishing tradition, socio-cultural customs and geographic location, displays a very high consumption of fish ${ }^{19}$. The aims of the present study were to estimate the intake of mercury among participants in the European Prospective Investigation into Cancer (EPIC) cohort of Gipuzkoa, and also to validate the estimation of mercury exposure due to diet, obtained with the EPIC standard interview, through the blood mercury level measured in a sample of individuals.

\section{Material and methods}

\section{Cobort participating in the EPIC study}

The EPIC cohort in Gipuzkoa was made up of a total of 8417 volunteers, comprised of women between the ages of 35 and 65, and men between the ages of 40 and 65 , residing in the province of Gipuzkoa ${ }^{20}$. The main source of the population for the cohort was active blood donors (75\%), complemented by other groups from the population (25\%) such as civil servants, employees of large companies (13\%) and the general population (12\%). The recruiting period for this cohort was from October 1992 to October 1995. The information on food intake was obtained through personal interviews using the diet history method ${ }^{21}$, through a computerised questionnaire designed especially for the study and validated previously $^{22-24}$. The questionnaire was structured according to occasions of food intake (breakfast, mid-morning snack, aperitif, lunch, tea, afternoon snack, dinner, and eating between meals). Information was gathered on the frequency and amounts of all foods and drinks consumed at least once every 15 days in the year prior to the interview, considering seasonal, weekend and holiday variations. The amounts were assessed through a series of 35 sets of photographs of simple foods, mixed foods and drinks in three different portion sizes. Foods without photographs were quantified using previously established criteria: units, standard kitchen measurements or photographs of similar foods.

Each one of the cohort members had $30 \mathrm{ml}$ of blood drawn using three monovette syringes, two with trisodium citrate as an anticoagulant and the third without anticoagulant. Samples were processed to separate plasma, serum, buffy coat and red blood cells. The blood fractions were then aliquoted into $0.5 \mathrm{ml}$ plastic tubes (straws) and stored in liquid nitrogen $\left(-180^{\circ} \mathrm{C}\right)$ until the analyses were carried out ${ }^{20}$.

In order to ascertain the most frequently consumed species of fish, the daily amount of each species consumed by the group was calculated, along with the daily number of individual consumers.

\section{Determination of the amount of mercury contained in fish}

The mercury content of the species of fish most frequently consumed by the EPIC cohort was obtained from two sources. On the one hand, information was supplied by the Food Chemical Surveillance Programme in the Basque Country. The method used by this programme is known as the 'market basket' method. The 91 products making up the market basket are purchased each month in a different town in the Basque Country. These towns are selected each year among those having over 5000 inhabitants using a random sampling system in which the probability of being selected is greater for those towns with a greater number of inhabitants ${ }^{25,26}$. This programme performs periodic measurements of chemical contaminants existing in the foods that make up the average diet of the Basque population.

On the other hand, for some species, in order to complete the number of samples, ad boc sampling was performed using a similar methodology.

The method used was based on combustion of the sample in a stream of oxygen, retention of the mercury in amalgam, liberation and determination of the element through cold vapour/atomic absorption. Total mercury was determined without differentiating between organic and inorganic. The device used was an Altech instrument, 
Table 1 Species of fish most commonly consumed by the EPIC Gipuzkoa cohort

\begin{tabular}{lccc}
\hline Fish species & $\begin{array}{c}\text { Number of meals } \\
\text { of fish intake }\end{array}$ & $\begin{array}{c}\text { Total daily } \\
\text { intake (g) }\end{array}$ & $\begin{array}{r}\text { Total daily } \\
\text { intake (\%) }\end{array}$ \\
\hline Hake (Merluccius merlucciius) & 4098 & 129232.7 & 21.0 \\
Whiting (Merluccius merluccius) & 3111 & 95832.4 & 15.5 \\
Horse-mackerel (Trachurus trachurus) & 2601 & 46169.4 & 7.5 \\
Unspecified white fish & 2464 & 44714.2 & 7.3 \\
Anchovies (Engraulis encrashicholus) & 4618 & 41347.5 & 6.7 \\
Cod (fillet) (Pollachius pollachius) & 2047 & 37802.7 & 6.1 \\
Megrim (Lepidorhombus boscil) & 1481 & 36686.8 & 6.0 \\
Canned tuna in oil (Thunnus tynnus) & 3749 & 18066.4 & 2.9 \\
Sole (Solea vulgaris vulgaris) & 718 & 13851.3 & 2.2 \\
Sardines (Sardina pilchardus) & 1099 & 13574.8 & 2.2 \\
Shrimp (Parapenaeus longirostris) & 3266 & 11213 & 1.8 \\
Pout (Trisopterus luscus) & 427 & 9513.4 & 1.5 \\
Unspecified blue fish & 665 & 9139.2 & 1.5 \\
Haddock (Gadus merlangus) & 431 & 8968.5 & 1.5 \\
Unspecified molluscs & 2860 & 8019.3 & 1.3 \\
Monkfish (Gadus poutassou) & 437 & 6905.6 & 1.1 \\
Common cuttlefish (Sepia officinalis) & 2388 & 6884.4 & 1.1 \\
Salted cod (Pollachius pollachius) & 664 & 6710.5 & 1.1 \\
Tuna (Thunnus tynnus) & 642 & 6397.75 & 1.0 \\
Small cuttlefish (Loligo vulgaris) & 632 & 6261.5 & 1.0 \\
Unspecified fish & 319 & 5308.08 & 0.9 \\
Atlantic bonito (Sarda sarda) & 429 & 3687.4 & 0.6 \\
Canned sardines in oil & 241 & 2848.81 & 0.5 \\
Squid (Loligo vulgaris) & 203 & 1334.31 & 0.2 \\
Canned Atlantic bonito in oil (Sarda sarda) & 181 & 939.63 & 0.2 \\
Mussels (Mytilus edulis) & 52 & 322.8 & 0.1 \\
& & & $92.8 \%$ \\
Total & 3923 & 571732.4 & \\
\hline & & & \\
\hline
\end{tabular}

model AMA-254. The detection and quantification limits were $0.5 \mathrm{ng} \mathrm{g}^{-1}$ and $1.0 \mathrm{ng} \mathrm{g}^{-1}$, respectively ${ }^{26}$.

\section{Estimation of mercury intake for each individual in the EPIC cobort}

To estimate the mercury intake for each individual in the EPIC cohort (8417), an arithmetic calculation was performed by multiplying the median amount of mercury in each species of fish by the number of grams of that species consumed per day. In order to estimate the intake of methylmercury, we assumed that the amount of methylmercury from fish was between $70 \%$ and $90 \%{ }^{1}$.

\section{Validation of the estimation of mercury intake}

In order to validate the estimation of mercury intake, a random sample of 120 individuals stratified by fish consumption was selected from the EPIC cohort. Four strata were defined (consumption below $31 \mathrm{~g} \mathrm{day}^{-1}$, from 31 to $64 \mathrm{~g} \mathrm{day}^{-1}$, from 64 to $115 \mathrm{~g} \mathrm{day}^{-1}$, and greater than $115 \mathrm{~g} \mathrm{day}^{-1}$ ). For these individuals the concentration of $\mathrm{Hg}$ in erythrocytes was measured ${ }^{6,8,9}$. The method and the equipment used were the same as in analysis of the fish samples. Total mercury was determined without differentiating between organic and inorganic. The detection and quantification limits were $0.5 \mathrm{ng} \mathrm{ml}^{-1}$ and $1.0 \mathrm{ng} \mathrm{ml}^{-1}$, respectively.

In order to rule out problems due to external mercury contamination, 30 unused straws of the type normally used for biological samples were processed in the EPIC study, with Type I water (ISO 3696), a 0.8\% saline solution and citrate. The blind analysis used the same processing technique described above.

\section{Statistical analysis}

The statistical tests used were non-parametric tests such as the Kruskal-Wallis test, Kendall's correlation coefficient and a multiple regression model.

SPSS statistical software (version 8.0) was used for analysis of the data.

\section{Results}

\section{Most commonly consumed species of fish and their mercury content}

The average consumption of fish among those making up the cohort is $73.9 \mathrm{~g} \mathrm{day}^{-1}$. Males consumed an average of $88.6 \mathrm{~g} \mathrm{day}^{-1}$ of fish and women consumed $55.1 \mathrm{~g} \mathrm{day}^{-1}$. The proportion of consumers of fish was $99.01 \%$ for men and $98.61 \%$ for women. The mercury concentrations were obtained for 18 species of fresh fish including crustaceans and molluscs, three canned species, salted cod and four unspecified categories, making up $92.8 \%$ of the species most commonly consumed by the cohort as a whole (Table 1).

The number of samples of each species for which the mercury content was determined ranges from 6 for monkfish to 36 for Atlantic bonito/tuna, using the median of the mercury content expressed in $\mu \mathrm{g} \mathrm{kg}^{-1}$ (Table 2). 
Table 2 Number of samples and mercury content $\left(\mu \mathrm{g} \mathrm{kg}^{-1}\right)$ by species

\begin{tabular}{lcc}
\hline Fish species & $\begin{array}{c}\text { Number of } \\
\text { samples }\end{array}$ & $\begin{array}{c}\text { Mercury content } \\
\left(\mu \mathrm{kg}^{-1}\right) \text { median }\end{array}$ \\
\hline Hake (Merluccius merlucciius) & 25 & 117.6 \\
Whiting (Merluccius merluccius) & 25 & 50.1 \\
Horse-mackerel (Trachurus trachurus) & 24 & 80.4 \\
Unspecified white fish & - & $89.5^{\star}$ \\
Anchovies (Engraulis encrashicholus) & 24 & 35.0 \\
Cod (fillet) (Pollachius pollachius) & 27 & 60.2 \\
Megrim (Lepidorhombus boscii) & 25 & 57.4 \\
Canned tuna in oil (Thunnus tynnus) & 29 & 223.3 \\
Sole (Solea vulgaris vulgaris) & 24 & 43.9 \\
Sardines (Sardina pilchardus) & 24 & 75.7 \\
Shrimp (Parapenaeus longirostris) & 8 & 15.5 \\
Pout (Trisopterus luscus) & 23 & 169.5 \\
Unspecified blue fish & - & $81.5^{\star}$ \\
Haddock (Gadus merlangus) & 16 & 93.4 \\
Unspecified molluscs & - & $10.7^{*}$ \\
Monkfish (Gadus poutassou) & 6 & 76.05 \\
Common cuttlefish (Sepia officinalis) & 23 & 14.9 \\
Salted cod (Pollachius pollachius) & 25 & 52.5 \\
Tuna (Thunnus tynnus) & 36 & 308.0 \\
Small cuttlefish (Loligo vulgaris) & 23 & 14.9 \\
Unspecified fish & 36 & 87.6 \\
Atlantic bonito (Sarda sarda) & - & 308.0 \\
Canned sardines in oil & 11 & 63.6 \\
Squid (Loligo vulgaris) & 23 & 14.9 \\
Canned Atlantic bonito in oil (Sarda sarda) & 29 & 223.3 \\
Mussels (Mytilus edulis) & 18 & 11.0 \\
Total & 504 & - \\
\hline Avedage value of al the fish spes & & \\
\hline
\end{tabular}

${ }^{*}$ Average value of all the fish species of each subgroup white fish, fatty fish, molluscs and crustaceans.

\section{Validation}

The average amount of mercury in red blood cells was $17.9 \mu \mathrm{g} \mathrm{kg}^{-1}$, with $19.8 \mu \mathrm{g} \mathrm{kg}^{-1}$ in men and $16.3 \mu \mathrm{g} \mathrm{kg}^{-1}$ in women. The mercury content in red cells followed an upward slope as the consumption of fish increased $(P<$ $0.001)$, with a statistically significant relationship between fish consumption and the amount of mercury in red blood cells (Table 3). The model that best explains the variation in mercury concentration in red blood cells as a function of the daily fish intake may be expressed as follows:

$$
\ln (y)=0.006 a-0.02 b+2.417,
$$

where $y$ is the concentration of mercury in red blood cells $\left(\mu \mathrm{g} \mathrm{kg}^{-1}\right), a$ is the daily dietary intake of fish $\left(\mathrm{g} \mathrm{day}^{-1}\right)$ and $b$ is the daily dietary intake of vitamin $\mathrm{E}\left(\mu \mathrm{g}\right.$ day $\left.^{-1}\right)$.

The adoption of the multiple analysis model was confirmed by graphical study of the residuals. Different approaches were taken, and the model that best explains the variability of mercury in red blood cells is habitual consumption of fish and daily dietary intake of vitamin $\mathrm{E}$. No significant improvement was found in the model for other relevant variables such as sex, age, body mass index (BMI), energy intake, vitamin C, alcohol, consumption of medicaments, and the interactions between them.

This model explained $30 \%$ of the variance and the independence. Normality and homoscedasticity of the residues were checked.

Table 3 Mercury intake per week, determination of mercury in red blood cells in a sample of 120 individuals and daily vitamin E intake by fish consumption group

\begin{tabular}{llll}
\hline Fish intake $\left(\mathrm{g} \mathrm{day}^{-1}\right)$ & \multicolumn{1}{c}{$\begin{array}{c}\text { Hg intake }(\mu \mathrm{g} \text { week } \\
\text { arithmetic mean }\end{array}$} & $\begin{array}{c}\text { Mercury in red blood cells } \\
\left(\mu \mathrm{g} \mathrm{kg}^{-1}\right) \text { arithmetic mean }\end{array}$ & $\begin{array}{c}\text { Daily vitamin } \mathrm{E} \text { intake } \\
\left(\mu \mathrm{g} \mathrm{day}^{-1}\right) \text { arithmetic mean }\end{array}$ \\
\hline$\leq 31.1(n=30)$ & $12.16(6.3)^{\star}$ & $10.62(7.44)^{\star}$ & $12.97(8.44)^{\star}$ \\
$>31.1-64.5(n=30)$ & $26.65(10.3)$ & $15.02(9.01)$ & $11.93(6.71)$ \\
$>64.5-115.0(n=30)$ & $45.99(16.4)$ & $18.81(10.09)$ & $11.86(5.68)$ \\
$>115.0(n=29) \dagger$ & $84.55(34.4)$ & $21.60 \dagger(10.47)$ & $12.81(9.31)$ \\
& Kruskal-Wallis test $P=0.0001$ & Kruskal-Wallis test $P=0.0001$ & Kruskal-Wallis test $P>0.05$ \\
\hline
\end{tabular}

* Values in parentheses are standard deviations.

$\dagger$ Excluded one case of $192 \mu \mathrm{g} \mathrm{kg}{ }^{-1}$.

Kendall's correlation coefficient, fish consumption and $\mathrm{Hg}$ intake $=0.69(P<0.001)$

Kendall's correlation coefficient, fish consumption and $\mathrm{Hg}$ in red blood cells $=0.39(P<0.001)$

Kendall's correlation coefficient, $\mathrm{Hg}$ intake and $\mathrm{Hg}$ in red blood cells $=0.36(P<0.005)$. 
Table 4 Weekly intake of fish, mercury and methylmercury, and percentage of PTWI* in the EPIC Gipuzkoa cohort (mean and 75th, 95th and 99th percentiles)

\begin{tabular}{|c|c|c|c|c|c|c|}
\hline & & Mean & 75th percentile & 95th percentile & 99th percentile & Maximum \\
\hline \multirow[t]{5}{*}{ Men } & Fish intake $\left(\mathrm{g} \mathrm{week}^{-1}\right)$ & 606.1 & 784.7 & 1251.8 & 1787.0 & 3349.1 \\
\hline & Mercury $\left(\mu \mathrm{g} \text { week }^{-1}\right)^{\prime}$ & 48.3 & 62.7 & 106.6 & 158.5 & 350.3 \\
\hline & $\%$ of PTWI & 12 & 16 & 27 & 40 & 82 \\
\hline & Methylmercury ( $\mu \mathrm{g}$ week $^{-1}$ ) & 43.4 & 56.4 & 95.9 & 142.6 & 315.3 \\
\hline & $\%$ of PTWI & 16 & 21 & 37 & 55 & 112 \\
\hline \multirow[t]{5}{*}{ Women } & Fish intake $\left(\mathrm{g}\right.$ week $\left.^{-1}\right)$ & 430.4 & 554.3 & 921.7 & 1333.9 & 2249.8 \\
\hline & Mercury ( $\mu \mathrm{g}$ week $^{-1}$ ) & 32.8 & 41.8 & 75.3 & 111.6 & 249.2 \\
\hline & $\%$ of PTWI & 10 & 13 & 23 & 33 & 56 \\
\hline & Methylmercury ( $\mu \mathrm{g} \mathrm{week}^{-1}$ ) & 29.5 & 37.6 & 67.6 & 100.4 & 224.2 \\
\hline & $\%$ of PTWI & 13 & 17 & 32 & 45 & 77 \\
\hline
\end{tabular}

* Provisional Tolerable Weekly Intake (PTWI) ${ }^{44}: 35 \mu \mathrm{gg}^{-1}$ week $^{-1}$.

The results of the processing of straws with Type I water (ISO 3696), 0.8\% saline solution and citrate were negative.

\section{Estimated mercury intake}

The average amount of mercury ingested by men was $48.3 \mu$ g week $^{-1}, 12 \%$ of the Provisional Tolerable Weekly Intake (PTWI), and the maximum intake was $350.3 \mu \mathrm{g}$ week $^{-1}$ ( $82 \%$ of the PTWI). In women the average was $32.8 \mu \mathrm{g} \mathrm{week}^{-1}$ (10\% of the PTWI) and the maximum was $249.2 \mu \mathrm{g} \mathrm{week}^{-1}$ (56\% of the PTWI). The average intake of methylmercury for men (assuming that 90\% of the mercury was methylmercury) was $43.4 \mu \mathrm{g}_{\text {week }}{ }^{-1}$ (16\% of the PTWI) and the highest amount consumed was $315.3 \mu \mathrm{g} \mathrm{week}^{-1}$ (112\% of the PTWI). In women the average was $29.5 \mu \mathrm{g} \mathrm{week}^{-1}$ (13\% of the PTWI) and the maximum was $224.2 \mu \mathrm{g}$ week $^{-1}$ (77\% of the PTWI) (Table 4).

If $70 \%$ of the mercury contained in fish is indeed methylmercury, $14 \%$ of the men and $8 \%$ of the women would be exceeding the maximum limit permitted by the United States Environmental Protection Agency (USEPA). The average risk index (methylmercury intake per day/ Oral Reference Dose (RfD)) is 0.60 for men, with a value of 0.49 for women. Under the hypothesis that $90 \%$ of mercury is methylmercury, these indices become 0.77 and 0.63 , respectively. Therefore $25 \%$ of men and $15 \%$ of women would be exceeding the limit (Table 5).

\section{Discussion}

These fish intake data confirm a pattern of very high consumption of fish in the Basque Country in particu$\operatorname{lar}^{27-33}$.

As a result of the variability in mercury content of the fish, the value selected for performing the mercury assignments was the median. Monkfish and shrimp presented low mercury content and very low variability. Tuna and bonito, the species of the largest size, were those with the highest concentrations, reflecting the bioaccumulation of mercury in the food chain ${ }^{34}$. The mercury contents found were much lower than $1 \mathrm{ppm}$, the limit set by Spanish legislation ${ }^{35}$. These concentrations of mercury were, in general, lower than those found on the Spanish Mediterranean coast $^{36}$.

As the consumption of fish increased, the concentration of mercury in red blood cells increased significantly (Table 3), in accordance with previous studies indicating that the methylmercury in blood is concentrated in red blood cells ${ }^{12,37,38}$. Several studies have shown that dental fillings can liberate mercury that may be absorbed by the digestive $\operatorname{tract}^{15,16}$. We lacked statistics on the number of dental fillings in individuals in the sample, which prevents us from adjusting for this variable. Nevertheless, it has been suggested that there is not sufficient evidence that methylation of inorganic mercury is produced in live human organisms ${ }^{39}$, in spite of the fact that some studies

Table 5 Daily intake of fish and methylmercury $(\mathrm{MeHg})$ in relation to the RfD* in the EPIC Gipuzkoa cohort (mean and 75th, 95th and 99th percentiles)

\begin{tabular}{|c|c|c|c|c|c|c|c|}
\hline & & & Mean & 75th percentile & 95th percentile & 99th percentile & Maximum \\
\hline \multirow[t]{5}{*}{ Men } & & Fish intake $\left(\mathrm{g} \mathrm{day}^{-1}\right)$ & 88.6 & 112.1 & 178.8 & 255.3 & 478.4 \\
\hline & \multirow[t]{2}{*}{$70 \% \mathrm{MeHg}$} & $\mathrm{MeHg}\left(\mu \mathrm{g} \mathrm{day}^{-1}\right)$ & 4.8 & 6.3 & 10.7 & 15.8 & 35 \\
\hline & & Risk index & 0.60 & 0.78 & 1.36 & 1.99 & 4.12 \\
\hline & \multirow[t]{2}{*}{$90 \% \mathrm{MeHg}$} & $\mathrm{MeHg}\left(\mu \mathrm{g} \mathrm{day}^{-1}\right)$ & 6.2 & 8.1 & 13.7 & 20.4 & 45.0 \\
\hline & & Risk index & 0.77 & 1.01 & 1.74 & 2.56 & 5.30 \\
\hline \multirow[t]{5}{*}{ Women } & & Fish intake $\left(\mathrm{g} \mathrm{day}^{-1}\right)$ & 55 & 70 & 116 & 172 & 224 \\
\hline & \multirow[t]{2}{*}{$70 \% \mathrm{MeHg}$} & $\mathrm{MeHg}\left(\mu \mathrm{g} \mathrm{day}^{-1}\right)$ & 3.2 & 4.2 & 7.5 & 11.1 & 15.2 \\
\hline & & Risk index & 0.49 & 0.63 & 1.16 & 1.66 & 2.81 \\
\hline & \multirow[t]{2}{*}{$90 \% \mathrm{MeHg}$} & $\mathrm{MeHg}\left(\mu \mathrm{g} \mathrm{day}^{-1}\right)$ & 3.4 & 4.9 & 8.4 & 12.1 & 19.5 \\
\hline & & Risk index & 0.63 & 0.82 & 1.50 & 2.13 & 3.62 \\
\hline
\end{tabular}

* Oral Reference Dose $(\mathrm{RfD})^{46}: 0.1 \mu \mathrm{g} \mathrm{kg}^{-1}$ day $^{-1}$. 
do indicate this ${ }^{40,41}$. Furthermore, methylmercury may undergo a low-intensity process of demethylation and turn into inorganic mercury. This would depend on the duration and intensity of the exposure to methylmercury, and the time that has passed since the period of exposure ended $^{16}$. Vitamin $\mathrm{E}$ would be playing a leading role in protecting cellular membranes from methylmercury ${ }^{17}$. The main problem presented by the determination of mercury is the possible contamination that may occur as a result of reagents and the environment during the sample preparation process and in the subsequent chemical analysis $^{42}$. The negative results found in the mercury determination tests performed on straws and different solutions used in the processing of biological samples exclude a possible confusion factor.

Exposure to methylmercury will vary according to the amount of it contained in the fish ${ }^{43}$. It has been stated that between $70 \%$ and $90 \%$ of the total mercury detected in fish is methylmercury ${ }^{1}$. We have considered these two values as hypotheses to estimate the risk involved in the most favourable and least favourable situation, which have been carried out by taking into consideration the values put forward for the general population by the World Health Organization (WHO) and for pregnant women by the USEPA, respectively.

Taking the PTWI (put forward by the WHO) of mercury as a reference, no individual exceeded the recommended values $\left(5 \mu \mathrm{g} \mathrm{kg}^{-1} \mathrm{day}^{-1}\right)^{44}$. The highest intake was reported for a man who worked in a restaurant and consumed large amounts of fish. Assuming that 90\% of mercury in fish is methylmercury, this man would exceed the recommended values $\left(3.3 \mu \mathrm{g} \mathrm{kg}^{-1} \mathrm{day}^{-1}\right)$ by $12 \%{ }^{45}$. Assuming that methylmercury comprises $70 \%$ of the mercury in fish, no individual exceeded the recommended maximum (Table 4).

The USEPA ${ }^{46}$ suggests the Oral Reference Dose (RfD) for methylmercury to be from 0.3 to $0.1 \mu \mathrm{g} \mathrm{kg}^{-1} \mathrm{day}^{-1}$, based on the consideration of adverse intrauterine neurological effects on the foetus and retarded psychomotor development in the future. As such this value would only apply to pregnant women. For all that, these values have been applied to any age and sex in our cohort. Under the hypothesis that methylmercury makes up $70 \%$ of the mercury in fish and taking the limit of $0.1 \mu \mathrm{g} \mathrm{kg}^{-1} \mathrm{day}^{-1}$ for the RfD, $14 \%$ of the men and $8 \%$ of the women would be exceeding the maximum daily intake. If we assume that methylmercury makes up $90 \%$ of the total mercury, $25 \%$ of the men and $15 \%$ of the women exceeded the recommended values. Taking the value of $0.3 \mu \mathrm{g} \mathrm{kg}^{-1}$ day $^{-1}$ as a reference, 23 people $(0.3 \%$ of the cohort) exceeded this value under the hypothesis that methylmercury is $90 \%$ of the total mercury.

We have studied the relationship between mercury ingestion and possible risks to the foetus among women in the age group 35-44 years (the only women of fertile age in our study). It has been observed that this age group has the lowest rate of fish ingestion (401 $\mathrm{g} \mathrm{week}^{-1}$, compared with $451.55 \mathrm{~g} \mathrm{week}^{-1}$ among the rest of the women in the cohort). Taking as a reference point the PTWI, none of them were in a risk situation. Taking as a reference point the RfD, $6 \%$ and $13 \%$ of them exceeded the recommended levels depending on whether the level of methylmercury was $70 \%$ or $90 \%$, respectively. But if the RfD were $0.3 \mu \mathrm{g} \mathrm{kg}^{-1} \mathrm{day}^{-1}$, none of them would be in a risk situation.

Although a variable percentage of the population in this cohort (between 10\% and 20\% of the cohort, depending on the most extreme risk circumstances found in the literature) may be ingesting amounts of mercury greater than the reference value (RfD), this does not necessarily imply harmful effects for health. This is because the RfD is a very conservative reference value based on theoretical considerations in a situation of extreme danger for the foetus. The RfD incorporates some degree of uncertainty, perhaps by one order of magnitude ${ }^{47}$. Different studies published have also shown that relatively large percentages of the population in the USA are ingesting amounts of methylmercury over this limit ${ }^{33}$ without any apparent danger to health.

Among the different studies published regarding the intake of methylmercury and its effects on health, perhaps those having the greatest similarity with our situation are those developed among populations whose diet includes large quantities of fish. In the Seychelles islands, where $85 \%$ of the population eats seafood on a daily basis, longitudinal analyses have been carried out over different periods of time among over 700 mother-and-child pairs, $75 \%$ of which ate fish from 10 to 14 times per week. No detrimental effect was found on cognitive or language skills or on behaviour up to the age of 66 months ${ }^{48}$.

On the other hand, the healthful effects of the consumption of fish should also be considered so as not to focus exclusively on eventual harmful effects. A diet including fish is a healthy one as it supplies high-quality proteins and, for its n-3 polyunsaturated fatty acid (PUFA), especially eicosapentaenoic and docosahexaenoic fatty acids. PUFAs are important to optimal development of the brain and retina, for proper maturing of the visual cortex and motor development in children ${ }^{49}$. Although not all studies indicate a protective effect, the consumption of fish reduces the risk of coronary disease ${ }^{50}$. Last but not least, vitamin $\mathrm{E}$ and selenium found in fish help to offset the effects of methylmercury ${ }^{8-17}$.

The Oral Reference Dose (RfD) criteria must be considered with a certain degree of care, as they are based on data supplied from an outbreak of mass poisoning through contaminated cereals in Iraq in 1971 and 1972, and their use has been questioned in the calculation of risk of low-level exposure to methylmercury from the consumption of fish ${ }^{51,52}$.

For the future, we believe that the amount of mercury in fish must continue to be closely monitored, in order to 
evaluate the health risks for the population. This is especially important insofar as international trade processes are leading to increasing availability of fish for our consumption from any part of the world. Furthermore, it would be important to quantify the amount of methylmercury contained in the fish that we consume, as this is the compound that could eventually cause human health problems.

\section{Acknowledgements}

To Jone Segués for help in reviewing the surveys, to José Manuel Herzog, whose work at the fish market was essential for getting fish samples, to Mercedes Jalón and Inés Urieta of the Food Chemical Surveillance in the Basque Country Program the most heart-felt gratitude for your work, which has been inspirational for the present study and, no doubt, will inspire others.

\section{References}

1 Agency for Toxic Substances and Disease Registry. Mercury toxicity. Am. Fam. Physician 1992; 46: 1731-41.

2 Berlin M. Dose-response relations and diagnostic indices of mercury concentrations in critical organs upon exposure to mercury and mercurials. In: Nordberg GF, ed. Effects and Dose-Response Relationship of Toxic Metals. Amsterdam: Elsevier Scientific Publishing Company, 1979; 235-45.

3 Clarkson TW. Mercury: major issues in environmental health. Environ. Health Perspect. 1992; 100: 31-8.

4 International Programme on Chemical Safety (ICPS). Methylmercury. Environmental Health Criteria 101. Geneva: World Health Organization, 1990

5 Langlois C, Langis R. Presence of airborne contaminants in the wildlife of northern Quebec. Sci. Total Environ. 1995; 160-161: 391-402.

6 Staveland G, Marthinsen Y, Norheim G, Julshamn K. Levels of environmental pollutants in flounder (Platichthys flesus L.) and cod (Gadus morbua L.) caught in the waterway of Glomma, Norway. II. Mercury and arsenic. Arch. Environ. Contam. Toxicol. 1993; 24: 187-93.

7 Fitzgerald WF, Clarkson TW. Mercury and monomethylmercury: present and future concerns. Environ. Health Perspect. 1991; 96: 159-66.

8 Svensson BG, Schutz A, Nilsson A, Akesson Y, Skerfving S. Fish as a source of exposure to mercury and selenium. Sci. Total Environ. 1992; 126: 61-74.

9 Buzina R, Stegnar P, Buzina-Suboticanec K, Horvat M, Petric Y, Farley TM. Dietary mercury intake and human exposure in an Adriatic population. Sci. Total Environ. 1995; 170: 199-208.

10 Svensson BG, Nilsson A, Jonsson E, et al. Fish consumption and exposure to persistent organochlorine compounds, mercury, selenium and methylamines among Swedish fishermen. Scand. J. Work Environ. Health 1995; 21: 96105.

11 Langworth S, Elinder CG, Gothe CJ, Vesterberg O. Biological monitoring of environmental and occupational exposure to mercury. Int. Arch. Occup. Environ. Health 1991; 63: 161-7

12 Schweinsberg F. Risk estimation of mercury intake from different sources. Toxicol. Lett. 1994; 72: 345-51.

13 Mackert JR. Factors affecting estimation of dental amalgam mercury exposure from measurements of mercury vapour levels intra-oral and expired air. J. Dent. Res. 1987; 66 : 1775-80.

14 Berglund A. Estimation by a 24-hour study of the daily dose of intra-oral mercury vapor inhaled after release from dental amalgam. J. Dent. Res. 1990; 69: 1646-51.

15 Clarkson TW, Hursh JB, Sager PR, Syversen TLM. Mercury. In: Clarkson TW, Friberg L, Nordberg GF, Sager PR, eds. Biological Monitoring of Toxic Metals. New York: Plenum Press, 1988; 196-246.

16 International Programme on Chemical Safety (ICPS). Inorganic Mercury. Environmental Health Criteria 118. Geneva: World Health Organization, 1991.

17 Lauwerys R. Toxicología Industrial e Intoxicaciones Profesionales. Barcelona: Masson SA, 1994; 153.

18 Gunderson EL. FDA Total Diet Study, July 1986-April 1991, dietary intakes of pesticides, selected elements, and other chemicals. J. AOAC Int. 1995; 78: 910-21.

19 Departamento de Sanidad. Encuesta de Nutrición de la Comunidad Autonoma del País Vasco. Vitoria-Gasteiz: Servicio Central de Publicaciones del Gobierno Vasco, 1994.

20 Grupo EPIC de España. Estudio prospectivo Europeo sobre dieta, cáncer y salud. Med. Clin. (Barc.) 1994; 102: 781-5.

21 Burke BS. The dietary history as a tool in research. J. Am. Diet. Assoc. 1947; 23: 104-11.

22 Group EPIC of Spain. Validity and reproducibility of a diet history questionnaire in Spain. I. Foods. Int. J. Epidemiol. 1997; 26: S91-9.

23 Group EPIC of Spain. Validity and reproducibility of a diet history questionnaire in Spain. II. Nutrients. Int. J. Epidemiol. 1997; 26: S100-9.

24 Group EPIC of Spain. Validity and reproducibility of a diet history questionnaire in Spain. III. Biochemical markers. Int. J. Epidemiol. 1997; 26: S110-7.

25 Urieta I, Jalón M, García J, Gonzalez de Galdeano L. Food surveillance in the Basque Country (Spain). I. The design of a total diet study. Food Addit. Contam. 1991; 3: 371-80.

26 Departamento de Sanidad, Gobierno Vasco. Vigilancia de la Contaminación Química de los Alimentos en la Comunidad Autónoma del País Vasco 1990-1995. Vitoria-Gasteiz: Servicio Central de Publicaciones del Gobierno Vasco, 1997; 19-24.

27 Rodriguez Artalejo F, Banegas JR, Graciani MA, Hernandez Vecino R, Rey Calero J. El consumo de alimentos y nutrientes en España en el periodo 1940-1988. Análisis de su consistencia con la dieta mediterranea. Med. Clin. (Barc.) 1996; 106: 161-8.

28 Rodriguez Artalejo F, Graciani MA, Banegas JR, Martín Moreno JM. El consumo de alimentos y nutrientes en España en el periodo 1940-1988 (y II). Un estudio comparativo de las principales fuentes de información sobre consumo alimentario. Med. Clin. (Barc.) 1996; 107: 446-52.

29 Moreiras-Varela O. The mediterranean diet in Spain. Eur. J. Clin. Nutr. 1989; 43(Suppl. 2): 83-7.

30 Peattie ME, Buss DH, Lindsay DG, Smart GA. Reorganization of the British total diet study for monitoring food constituents from 1981. Food Chem. Toxicol. 1983; 21: 503-7.

31 Pennington JA. Revision of the Total Diet Study food list and diets. J. Am. Diet. Assoc. 1983; 82: 166-73.

32 Gussow JD. Mediterranean diets: are they environmentally responsible? Am. J. Clin. Nutr. 1995; 61(Suppl): 1383S-9S.

33 Stern AH, Korn LR, Ruppel BE. Estimation of fish consumption and methylmercury intake in the New Jersey population. J. Expos. Anal. Environ. Epidemiol. 1996; 6: 503-25.

34 Wiener JG. Bioaccumulation of mercury in fish. Proceedings of the Nation's Forum on Mercury in Fish, New Orleans, LA, 27-29 September 1995. EPA 823 R-95-002. Washington, DC: US Environmental Protection Agency, Office of Water, 1995; 41-7. 
35 Ministerio de Sanidad y Consumo. Orden de 2 de Agosto de 1991 del Ministerio de Sanidad y Consumo por la que se aprueban las normas microbiológicas, los límites de contenido en metales pesados para los productos de la pesca y de la acuiculturra. BOE No. 195. Madrid: Ministerio de Sanidad, 1991.

36 Schuhmacher M, Batiste J, Bosque MA, Domingo JL, Corbella J. Mercury concentrations in marine species from the coastal area of Tarragona Province, Spain. Dietary intake of mercury through fish and seafood consumption. Sci. Total Environ. 1994; 156: 269-73.

37 Fldspang A, Hansen JC. Dietary intake of methylmercury as a correlate of gestational length and birth weight among newborns in Greenland. Am. J. Epidemiol. 1990; 132: $310-7$.

38 Grandjean P, Weihe P, Jørgensen PJ, Clarkson T, Cernichiari E, Vider $\varnothing$ T. Impact of maternal seafood diet on fetal exposure to mercury, selenium, and lead. Arch. Environ. Health 1992; 47: 185-95.

39 Barregard L, Horvat M, Schütz A. No indication of in vivo methylation of inorganic mercury in chloralkali workers. Environ. Res. 1994; 67: 160-7.

40 Aitio A, Valkonen S, Kivistö H, Yrjänheikki E. Effect of occupational mercury exposure on plasma lysosomal hydrolases. Int. Arch. Occup. Environ. Health 1983; 53: $139-47$.

41 Chang SB, Siew C, Gruninger SE. Examination of blood levels of mercurials in practicing dentists using cold-vapor atomic absorption spectrometry. J. Anal. Toxicol. 1987; 11: $149-53$.

42 Brune D, Nordberg GF, Vesterberg O, Gerhardssson L, Wester PO. A review of normal concentrations of mercury in human blood. Sci. Total Environ. 1991; 100: $235-82$.

43 Oskarsson A, Json Lagerkvist B, Ohling B, et al. Mercury levels in the hair of pregnant women in a polluted area in Sweden. Sci. Total Environ. 1994; 151: 29-35.

44 World Health Organization. Evaluation of Certain Food Additives and the Contaminants Mercury, Lead, and Cadmium. Sixteenth Report of the Joint FAO/WHO Expert Committee on Food Additives. WHO Technical Report Series, No. 505. Geneva: World Health Organization, 1972.

45 World Health Organization. Evaluation of Certain Food Additives and Contaminants. Thirty-third Report of the Joint FAO/WHO Expert Committee on Food Additives. WHO Technical Report Series, No. 776. Geneva: World Health Organization, 1989.

46 US Environmental Protection Agency. Oral Reference Dose for Methylmercury. IRIS (Integrated Risk Information System) [Online]. Available at http://toxnet.nlm.nih.gov/ cgi-bin/sis/search/f?./temp BAAKEai60:1. 5 January 1995.

47 US Environmental Protection Agency. Glossary of Risk Assessment Related Terms. IRIS (Integrated Risk Information System) [Online]. Available at http://www.epa.gov/iris/ gloss8.htm. 3 May 2001.

48 Davidson PW, Myers GJ, Cox C, et al. Effects of prenatal and postnatal methylmercury exposure from fish consumption on neurodevelopment: outcomes at 66 month of age in the Seychelles Child Development Study. JAMA 1998; 280 701-7.
49 Uauy-Dagach R, Mena P. Nutritional role of omega-3 fatty acids during the perinatal period. Clin. Perinatol. 1995; 22: $157-75$.

50 Daviglus ML, Stamler J, Orencia AJ, et al. Fish consumption and the 30-year risk of fatal myocardial infarction. N. Engl.J. Med. 1997; 336: 1046-53.

51 Egeland GM, Middaugh JP. Policy Forum: Balancing fish consumption benefits with mercury exposure. Science 1997; 278: 1904-5.

52 Clarkson T, Cox C, Davidson PW, Myers GJ. Mercury in fish. Science 1998; 279: 459-60.

\section{Appendix}

EPIC (European Prospective Investigation into Cancer and Nutrition) is a European study co-ordinated by the Unit of Nutrition and Cancer of the International Agency for Research on Cancer (IARC). The EPIC Group of Spain comprises:

- Antonio Agudo, Instituto Catalán de Oncología, Barcelona

- Pilar Amiano, Departamento de Sanidad del Gobierno Vasco, San Sebastián

- Ana Barcos, Departamento de Salud, Navarra

- Aurelio Barricarte, Departamento de Salud, Navarra

- Jose M Begiristain, Departamento de Sanidad del Gobierno Vasco, San Sebastián

- $\mathrm{M}^{\mathrm{a}}$ Dolores Chirlaque, Consejería de Sanidad y Política Social, Murcia

- Miren Dorronsoro, Departamento de Sanidad del Gobierno Vasco, San Sebastián

- Cristina Lasheras, Consejería de Sanidad y Servicios Sociales, Asturias

- Carmen Martínez, Escuela Andaluza de Salud Pública, Granada

- Carmen Navarro, Consejería de Sanidad y Política Social, Murcia

- Guillem Pera, Institut de Recerca Epidemiologica i clinica, Mataró

- José R Quirós, Consejería de Sanidad y Servicios Sociales, Asturias

- Mauricio Rodríguez, Escuela Andaluza de Salud Pública, Granada

- $\mathrm{M}^{\mathrm{a}}$ José Tormo, Consejería de Sanidad y Política Social, Murcia

- Carlos A González (Study Coordinator and Principal Investigator in Spain), Instituto Catalán de Oncología, Barcelona. 